\title{
DEVELOPMENT OF GRADE 10 STUDENTS' SCIENTIFIC ARGUMENTATION THROUGH THE SCIENCE-TECHNOLOGY-SOCIETY LEARNING UNIT ON WORK AND ENERGY
}

\author{
Jirutthitikan Pimvichai $^{1}$ (D) Chokchai Yuenyong1 ${ }^{1}$ D, Khajornsak Buaraphan $^{2 *}$ D \\ ${ }^{1}$ Faculty of Education, Khon Kaen University (Thailand) \\ ${ }^{2}$ Institute for Innovative Learning, Mahidol University (Thailand) \\ fern_699@windowslive.com,ychok@kkku.ac.th, ${ }^{*}$ Correspondingauthor:khajornsak.bua@mabidol.ac.th
}

Received August 2018

Accepted March 2019

\section{Abstract}

This study aims to examine the effect of Science-Technology-Society (STS) learning unit on the Work and Energy topic in developing grade 10 students' scientific argumentation. The research participants were 20 grade 10 students at one secondary school located in Khon Kaen province, the Northeastern region of Thailand. The students' tasks, discourse and informal interview were collected and interpreted according to the Toulmin's Argument Pattern (TAP) framework. The findings revealed that the STS learning unit on Work and Energy could promote the participating students' scientific argumentation. That is, the students could generate more quality and effective scientific argumentation according to the TAP framework. There was a high number of quality scientific argumentation regarding Warrants, Qualifiers and Backing especially in the Decision Making and Socialization stages of STS approach. Also, the students normally applied their scientific understanding in creating their Grounds. The implication of this study are designing the appropriate STS workshop for training in-service science teachers to be able to understand about the STS approach and how to apply the STS approach in helping their students develop scientific argumentation.

Keywords - Scientific argumentation, Work and energy, Science-technology-society approach, Thailand.

\section{To cite this article:}

Pimvichai, J., Yuenyong, C., \& Buaraphan, K. (2019). Development of grade 10 students's scientific argumentation through the science-technology-society learning unit on work and energy. Journal of Technology and Science Education, 9(3), 428-441. https://doi.org/10.3926/jotse.527

\section{Introduction}

The National Education Act B.E. 2542 (Office of the National Education Commission, 1999) and Amendments (Second National Education Act B.E. 2545) (Office of the National Education Commission, 2002) emphasize the student-centered learning process where learners are regarded as being the most important. Thus, the teaching and learning process shall aim at enabling learners to develop themselves at their own pace and to develop their full potential. Educational institutions and agencies shall provide training in thinking process, management, how to face various situations and application of 
knowledge for obviating and solving problems. The ultimate goal of education aims at developing Thai citizen to cope with the economic, social and political growth of the countries in the ASEAN region.

Even though the Ministry of Education has been emphasized the student-centered teaching and learning process in Thailand since 1999, the teaching and learning process in many classrooms still focus on teacher-centered and teaching students to acquire good scores in school exams and, ultimately, the Ordinary National Education Test (ONET). In science learning, many students focus their learning on memorization of contents rather than practice an ability to critically think, logically analyze and systematically solve real problems. Also, there are a few connections between students' learning scientific knowledge and its application in their daily lives. This situation is harmful for the growth of Thailand because these youths will grow to become the quality Thai citizen in the near future (Office of the Education Council, 2011).

The new science curriculum emphasized science teaching and learning based on scientific inquiry that emphasizes learners construct knowledge by themselves through scientific inquiry process. One important process of scientific inquiry is scientific argumentation (Berland \& Reiser, 2009). There is a relationship between the scientific argumentation skill and scientific understanding. In science classroom, learners must utilize their scientific knowledge and cognitive process to generate scientific argumentation and participate in social process to communicate their arguments in communicative forms and exchange and defend them with their classmates. Thus, promoting scientific argumentation through scientific inquiry classrooms is important in helping learners reach learning objectives in science (Sampson, Grooms \& Walker, 2009).

The current science education movement needs students to attain good argumentative skills because there are various social-related scientific issues and conflicts to make arguments on them. This means that students are expected to be able to consider reliable evidence before making an opinion or a decision. In addition, students should be able to communicate their arguments with their peers who may agree or disagree with them. In argumentative process, students express their efforts in seeking for reliable evidence to confirm and make other side students agree with them (Toulmin, 2003).

The Science-Technology-Society (STS) is one of constructivist teaching approaches that can help students develop their ability to make arguments and defend their arguments by raising appropriate reliable data sources. The degree of reliability of data source can improve the effectiveness of decision-making process. The searching skills for reliable data and creating relevant arguments would enable students to comfortably participate in social discussion and allow them to be responsible for their social responsibility (Driver, Newton \& Osborne, 2000). When students learn how to create scientific arguments and develop the rationale behind such arguments, they will be able to integrate their scientific understanding with the real problem. In argumentation, students must be able to develop a sensible reason to support their argument until reach quality argumentation that greatly helps them solve issues or conflicts (Lin \& Mintzes, 2010).

However, there is no study about current situation of students' scientific argumentation in grade 10 science classrooms in Thailand. In addition, there are no study related to the utilization of STS approach in enhancing grade 10 students' scientific argumentation. These are two big gaps in the literature about STS approach and scientific argumentation that this study would like to contribute. Therefore, the research question of this study is: What are the effects of the STS learning unit in the Work and Energy topic in enhancing grade 10 students' scientific argumentation? So that, the objective of this study is: to examine the effect of the STS learning unit on the Work and Energy topic in enhancing grade 10 students' scientific argumentation.

\section{Literature Review}

This section presents the review of literature related to the national science education reform in Thailand, STS approach, scientific argumentation and enhancement of scientific argumentation through STS approach. 


\subsection{National Science Education Reform}

The second pave of national science education reform in Thailand had been started since the announcement of Constitution of the Kingdom of Thailand (B.E. 2540) in 1999. After that, in 2001, the Thailand government had announced the National Education Act B.E. 2542 that led to the proclamation of the new national curriculum namely the Basic Education Curriculum B.E. 2544 (Ministry of Education, 2001). In this new national curriculum, the learning subjects was divided into eight learning areas that science was included as one of them. The learning area of science aims to enable learners to link scientific knowledge with processes, acquire essential skills for investigation, build knowledge through investigative processes, seek knowledge and solve various problems. Learners are allowed to participate in all stages of learning, with activities organized through diverse practical work suitable to their levels. There were eight learning strands in the new national science curriculum including: Living Things and Processes of Life; Life and the Environment; Substances and Properties of Substances; Forces and Motion; Energy; Change Process of the Earth; Astronomy and Space; and Nature of Science and Technology. There were two brand new learning strands in this new science curriculum, that is, the Change Process of the Earth and Nature of Science and Technology learning strands.

\subsection{STS Approach}

The STS approach emphasizes students as being most important which is different from the traditional teaching method in a sense that the STS approach integrates science, technology and society together. Learning science is occurred in the technological and social context and then applied to society. In the STS classroom, students will feel that their learning is more meaningful because it is highly related to their lives as well as benefits to their society (Yuenyong, 2006). Thus, the STS approach encourages students to be more interested in science learning and regards science as a valuable method of learning inquiry. It also helps students realize that science and technology are things around them (Protjanatanti, 2001). In sum, the STS approach starts from bringing societal and environmental issues and requires students to develop and apply their technological and scientific knowledge and skill to solve the raised issues. At final, the students can plan their actions for sustaining their society (Aikenhead \& Ryan, 1992).

According to Yuenyong (2006), the STS approach is consisted of five stages: Identification of social issues, Identification of potential solutions, Need for knowledge, Decision-making and Socialization. In the Identification of Social Issues stage, a teacher encourages students to ask questions about the raised societal and environmental issues. The issues should be interesting and current controversial issues in the society. The students must be aware of the social problems due to appreciation of science and technology and their involvement in solving the issues. Then, the students go to the Identification of Potential Solutions stage. They will plan to find answers to the raised issues or problems. The students are required to review their existing knowledge and find more knowledge for finding the potential solution of the raised problems. In the Need for Knowledge stage, students are required to find out more knowledge or database in order to solve societal and science-related issues. The strategies in this stage include reading and reflection based upon the teacher's assigned documents or students' searched documents. The appropriate knowledge will lead the students to make good decision according to the raised issue. Then, students move to the Decision-making stage. They are required to analyze knowledge from the third stage and synthesize the potential or possible solutions of the raised issues. Then, the students have to make decisions for the problems. Finally, in the Socialization stage, students need to act as a citizen who take part in society. They are required to present their potential or possible solutions of the raised issues for solving problem.

\subsection{Scientific Argumentation}

Scientific argumentation is a part of communicative skills that is one important skill in learning science since science is based on reasonableness. Scientific argumentation is a process or action where a student expresses idea or provides a rationale against the others with supporting evidence. Stephen Toulmin (1958) stated about scientific argumentation a rebuttal of Toulmin (Toulmin's Argumentation Pattern: 
TAP) that is consisted of: Ground (Evidence), Claim, Warrant, Rebuttals (Counter argument), Backing (Supportive argument) and Qualifiers. Ground (Evidence) means that the student can use facts or evidence to prove his/her argument. The facts or evidence involved in the student argument aim to support student claim. Claim means that the student thinking of the argument. It is the student's most general statement in the disputation. It is also the student's common principle or affirmation made after student brainstorm in group. Warrant means that the student has the argument consisting of a title versus the claim with supporting data and has warranties or backings having no rebuttals. Warrant is a reason (e.g. rule, principle, etc.) that are proposed to justify the connections between the data and the knowledge claim, or conclusion. Rebuttals (Counter Argument) specify the conditions when the claim will not be true. Rebuttals express counter arguments or statements indicating circumstances when the general argument does not obtain true. Backing (Supportive Argument) is basic assumptions that are usually considered to be commonly agreed. Backing provides justification for particular warranties. Arguments do not necessarily prove the main point being argued but aims to prove that the warrants are true. Finally, Qualifiers specify the conditions under which the claim can be taken as true. Qualifiers represent the limitations of the claim (Toulmin, 2003).

\subsection{Enhancement of Scientific Argumentation Through STS Approach}

There are several constructivist teaching strategies having potential to promote students' scientific argumentation; one of them is the Science-Technology-Society (STS) approach. The STS approach is appropriate in promoting student scientific argumentation (Lin \& Mintzes, 2010) because it starts from the controversial issue or question raised by students. Students are aware of the raised issues and apply their scientific understanding and skills to seek information for the best solutions for solving problems or responding to the issues.

The STS approach encourages students as individuals or group to find out the ways for solving the real controversial issues or problems occurred in society. After that, students present their proposed solutions to the class and scientific argumentation then is conducted to find out the best possible solutions for those controversial issues or problems. In this case, teaching science by emphasizing argumentation helps students understand the targeted concept. During argumentation, students are required to utilize their scientific knowledge to explain and support their arguments (Erduran, Simon \& Osborne, 2004). The STS approach can promote students' development of scientific knowledge from social process since the nature of scientific knowledge is developed from social process. When students debate about various socialrelated scientific issues in the STS activity, they have chance to strengthen their scientific knowledge. Also, after argumentation, they have chance to make more reliable and appropriate decisions (Ziman, 1978). Individual students' argumentative skills are different due to the difference of their prior knowledge and experience regarding the raised issue. When individual grows older, their argumentative skills can be developed from facing various situations (Kuhn, 1993).

One problem of science education in Thailand is that science teaching and learning still focus on student test or exam scores rather than their ability to construct knowledge by themselves. Also, students lack an ability to make scientific argumentation that can affect their construction of scientific understanding. In Thailand, there is a lack of study related to the utilization of STS approach to enhance grade 10 students' scientific argumentation.

\section{Methodology}

This study employs a case study (Sturman, 1997) as research methodology to holistically study the complex phenomenon of students' scientific argumentation bounded in the science classrooms in the Northeastern region of Thailand.

\subsection{Data Collection}

The researchers developed the STS learning unit on the Work and Energy topic to enhance grade 10 students' scientific argumentation. Then, the learning unit was implemented with 20 grade 10 students in 
one secondary classroom located in Khon Kaen province, the Northeastern region of Thailand. The researchers collected data from students' tasks, discourse and informal interview. The teaching and learning in this science classroom were also videotaped. Also, the informal interviews with teachers and students were audiotaped.

\subsection{Data Analysis}

The researchers verbatim transcribed all videotapes and audiotapes. Then, the scientific argumentationrelated interactions in the classrooms were coded by employing the Toulmin's Argument Pattern (TAP) framework (2003).

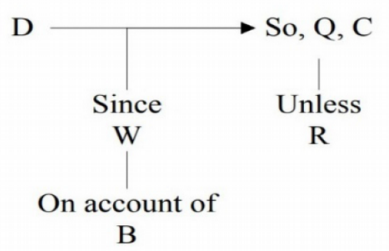

Figure 1. TAP analytical framework

Figure 1 shows the TAP analytical framework. Claim (C) is a viewpoint student would like to express and aims to persuade others. Warrant (W) establishes a cognitive interaction between the claim and the grounds. Therefore, W demands an implication to the underlying meaning that sheds light on the claim thanks to the grounds. The warrant's responsibility as a link is achieved by the Qualifiers (Q), in contrast, states the degree of strength or probability that the claim is true, indicating how sure the argument is. The next element is Rebuttals (R), counter-arguments or statements depicting situations where the argument fails to prove itself. A list of limitations and exceptions could be embedded in the R. Backing (B) further justifies the $\mathrm{W}$ with evidence arguing for the reasoning of the $\mathrm{W}$. The types of scientific argumentation can be classified into four types according to its complexity as how elaborate the evidence or grounds are provided, how compatible of examples as justification and the appearance of any rebuttals to counter-arguments.

On the other hand, in some cases, the hierarchy is less prominent between Type 3 and Type 4 due to the fact that Type 3 may embodies more well-established justifications with more extensive grounds than Type 4, whereas Type 4 may contain a very basic justification yet with rebuttal.

\begin{tabular}{|c|c|l|}
\hline $\begin{array}{c}\text { Type of scientific } \\
\text { argumentation }\end{array}$ & Code & \multicolumn{1}{c|}{ Description } \\
\hline 1 & AC & $\begin{array}{l}\text { A simple claim without justification or grounds versus another claim or } \\
\text { counterclaim. }\end{array}$ \\
\hline 2 & AG+ & $\begin{array}{l}\text { One or more claim(s) with simple justification or grounds (comprising } \\
\text { data, warrant, and/or qualifier and backing) but no rebuttal. }\end{array}$ \\
\hline 3 & AG ++ & $\begin{array}{l}\text { One or more claim(s) with more detailed justification or grounds } \\
\text { (comprising data, warrant, and/or qualifier and backing) but no } \\
\text { rebuttal. }\end{array}$ \\
\hline $4 \mathrm{~A}$ & AG+R & $\begin{array}{l}\text { One or more claim(s) with justification or grounds and with a rebuttal } \\
\text { that addresses a weakness of the opposing argument and/or provides } \\
\text { further support for one's earlier argument. }\end{array}$ \\
\hline $4 \mathrm{~B}$ & $\begin{array}{l}\text { One or more claim(s) with justification or grounds and with a } \\
\text { self-rebuttal that considers the limitation or weakness of one's own } \\
\text { argument. }\end{array}$ \\
\hline
\end{tabular}

Table 1. Types of scientific argumentation (Chin \& Osborne, 2010) 
The numbers in the codes of scientific argumentation do not hierarchically show their levels. Rather, the numerical order indicates the degree of complexity, within which Type 1 is the most rudimental, while Type 4 is more advanced.

\section{Results and Discussion}

The researchers employed the STS framework based on Yuenyong's (2006) in designing the STS learning unit in the Work and Energy topic for enhancing grade 10 students' scientific argumentation. The STS learning unit was consisted of 11 lesson plans. The main controversial societal issue for the STS learning unit was building safe playground for children. This issue may motivate students to begin to learn science in the realm of society through the utilization of relevant technology.

The STS learning unit on Work and energy topic helped the participating students deveop quality scientific argumentation. The following sections present the students' scientific argumentation in each stage of STS approach.

\begin{tabular}{|c|c|c|}
\hline Lesson plan & STS activities & Hour \\
\hline $\begin{array}{l}\text { (Work and } \\
\text { energy unit) } \\
1\end{array}$ & $\begin{array}{l}\text { 1. Identification of the social issues stage } \\
\text { - The teacher asks: What about the playground in your community, do you think is it } \\
\text { safe? } \\
\text { - Students watch three videoclips: Silent disasters from the playground (source: } \\
\text { https://www.youtube.com/watch?v } 55 \mathrm{x} 41 \text {-xZ9X8), Challenging the death swing } \\
\text { (source: https://www.tvpoolonline.com/content } / 226004) \text { and The most } \\
\text { dangerous slippery boards (source: } \underline{\text { https://www.youtube.com/watch? }} \\
\text { v=ZSjG6V9KJo) } \\
\text { 2. Identification of potential solutions stage } \\
\text { - Students develop possible solutions from their ideas and share to the classroom } \\
\text { - Students identify knowledge they need }\end{array}$ & 1 \\
\hline 2 & $\begin{array}{l}\text { 3. Need for knowledge stage } \\
\text { - Students do experiment on Potential and Kinetic Energy } \\
\text { - Students work in group about "How to play safe with several playing equipment in } \\
\text { playground" }\end{array}$ & 1 \\
\hline $3-4$ & $\begin{array}{l}\text { 3. Need for knowledge stage (continued) } \\
\text { - } \quad \text { Students do investigation about energy including both potential and kinetic energy }\end{array}$ & 2 \\
\hline 5 & $\begin{array}{l}\text { 4. Decision making stage } \\
\text { - Students list possible choices to make decisions how to develop and design playing } \\
\text { equipment in playground } \\
\text { - Students attend brainstorming for reaching arguments about fun and safe playing } \\
\text { - } \quad \text { Stuipment }\end{array}$ & 2 \\
\hline 6 & $\begin{array}{l}\text { 5. Socialization stage } \\
\text { - Students present works about fun and safe playing equipment to the classroom } \\
\text { - Students evaluate designed playing equipment of each group whether they will buy } \\
\text { or not buy it } \\
\text { Divide students into two groups (buy and not buy) and require them to debate }\end{array}$ & 1 \\
\hline $\begin{array}{c}\text { (Conservation } \\
\text { of engergy unit) } \\
7\end{array}$ & $\begin{array}{l}\text { 1. Identification of social issues stage } \\
\text { Students watch and ask question from the Khon Kaen flood clip (Ubonrat dam drains } \\
\text { water } 50 \text { million litrs a day) (https://www.youtube.com/watch?v=bhVoCwBnMlk) } \\
\text { 2. Identification of potential solutions stage } \\
\text { Students develop possible knowledge base for solutions and share their thoughts from } \\
\text { their own experiences in everyday life. Students come up with what kinds of knowledge } \\
\text { they may need e.g. conservation of energy: "No energy is lost or rebuiltbut energy can } \\
\text { change from one form to another". }\end{array}$ & 1 \\
\hline
\end{tabular}




\begin{tabular}{|c|c|c|}
\hline 8 & 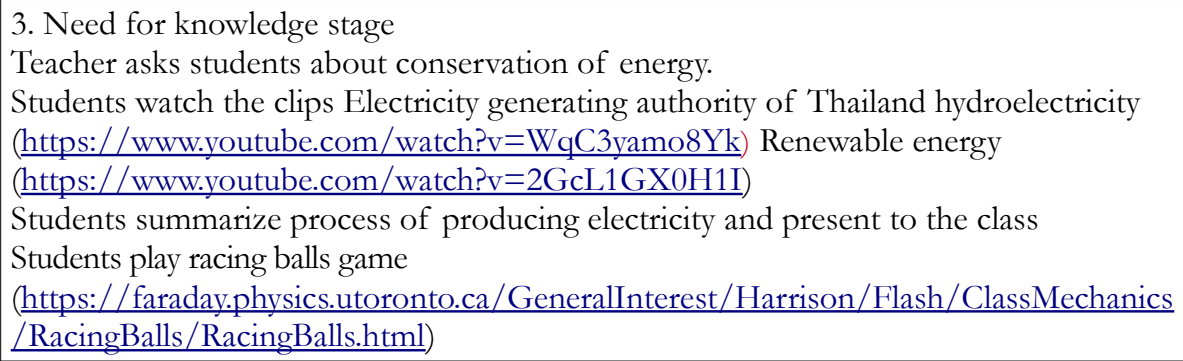 & 1 \\
\hline 9 & $\begin{array}{l}\text { 3. Need for knowledge stage } \\
\text { Students answer questions about the games } \\
\text { Students conclude mechanical, potential and kinetic energy } \\
\text { Teacher challenges students how the water could be used for generating electricity. } \\
\text { Students watch the system of power plant clip (https://www.youtube.com/watch? } \\
\text { v=WqC3yamo8Yk) and summarize the process of generating electricity. } \\
\text { Students discuss aabout "Producing electricity from solar energy is more cost effective } \\
\text { than producing electricity from Hydropower" } \\
\text { Students debate electric supply and demand and what sources of energy should be } \\
\text { used in generation in the power plant. }\end{array}$ & 1 \\
\hline 10 & $\begin{array}{l}\text { 4. Decision making stage } \\
\text { Students list possible ways to make decisions }\end{array}$ & 2 \\
\hline 11 & $\begin{array}{l}\text { 5. Socialization stage } \\
\text { Students share their ideas of decision making as exhibition in their school and reflect } \\
\text { what they learn from the unit }\end{array}$ & 1 \\
\hline
\end{tabular}

Table 2. The STS learning unit on Work and energy topic

\subsection{Identification of the Social Issues Stage}

Students were engaged in the societal and technological issues about playground. They could provide some claims about the dangerous of playground that represented various types of claims and categories of quality argumentation.

010 T: How do you think about this VDO clip? Is there any playground like this in your community?

012 S2: Yes, sir. We have swings in our community park.

014 S5: We have sliders. S6: We have see saw

024 T: Do those playground things safe for playing?

025 S5: Yes, they do. They have some handles around.

026 S6: It is dangerous sometime. My friends had broken head because they were moved down so fast on the slider.

027 T: Is there other playground thing dangerous?

028 S9: I think that the see saw is probably dangerous. It should have safety belt otherwise player maybe falling down.

029 S10: It is not dangerous, if we do not move it too high.

030 T: How do you know those playgrounds are dangerous?

031 S1: Some playground things could break our legs or hands.

032 S2: I think that leg could be wound.

033 S3: Harm or safety depends on the ways we play. If we do the right way, they all are safe.

034 S5: It is dangerous when we are careless.

036 S7: The very old playground things cause of harm. 
037 S8: If we apply more force on the swing, it will go too high and fast and cause danger.

$045 \mathrm{~T}$ : What are the factors influenced the safety standard of playground?

046 S1: The materials made playground are low quality such as plastic is too thin. The design of playground instruments are not appropriate or safe.

049 S6: If there are too many people play on the same playground thing, it may be overweight on that. This should be the case of accidents.

065 S3: I think that the slope of slider should not too high. The slope is cause of fun and harm.

066 S4: We may provide something to protect children when they stop at the bottom of slider.

067 S5: It should be something that is soft or providing water for coming down there - the sliders.

The students' scientific argumentation in this stage could be categorized into four types as Table. Half of the students' scientific argumentaiton belonged to a simple claim without justification or grounds versus another claim or counterclaim $\left(A_{C}\right)$ and one-third of them was is $A_{G+}$.

\begin{tabular}{|c|l|c|}
\hline Code & \multicolumn{1}{|c|}{ Description } & Frequency \\
\hline$A_{C}$ & $\begin{array}{l}\text { A simple claim without justification or grounds versus another claim or } \\
\text { counterclaim. }\end{array}$ & $23(50.00 \%)$ \\
\hline$A_{G+}$ & $\begin{array}{l}\text { One or more claim(s) with simple justification or grounds (comprising data, } \\
\text { warrant, and/or qualifier and backing) but no rebuttal. }\end{array}$ & $72(33.3 \%)$ \\
\hline$A_{G++}$ & $\begin{array}{l}\text { One or more claim(s) with more detailed justification or grounds } \\
\text { (comprising data, warrant, and/or qualifier and backing) but no rebuttal. }\end{array}$ & $4(8.69 \%)$ \\
\hline$A_{G+} \mathrm{R}$ & $\begin{array}{l}\text { One or more claim(s) with justification or grounds and with a rebuttal that } \\
\text { addresses a weakness of the opposing argument and/or provides further } \\
\text { support for one's earlier argument. }\end{array}$ & $46(100.00 \%)$ \\
\hline Total & \multicolumn{1}{|c|}{}
\end{tabular}

Table 3. Students' scientific argumentation in the Identification of the social issues stage

\subsection{Identification of the Potential Solution Stage}

The students tried to think about possible solutions for the playground issue. The students listed various fun and safe playground things included swing, slider, see-saw, spring board, and pull-up workout. The various types of claims and categories of quality of argumentation could be seen via students' discourse during their designing safety playground and presentation of possible solutions.

098 S1: It (slider) is too steep. People may be hurt their stomach because they are too fast moved.

099 S2: So, I will change the slope of slider.

101 S4: We may provide sand on the base of slider.

102 S5: How do you design safe slider?

103 S1: Provide some instruction or adult to take care children playing on it.

$\cdots$

111 S4: We may provide water on the base of slider. I have experience pull-up workout during raining. It was fun. It's my dream to play on the playground things like this. 
112 S5: If we provide something on the base of slider. Then, people will bounce off the ground.

113 S3: So, we may provide the net around the slider otherwise people may jump up and down away.

114 S6: The height of net should be provided around 6 meters, I think. It should be not dangerous. So, no need adult to give advice.

115 S7: The player should wear a helmet.

116 S5: What is the material of the net?

118 S6: It should be made from metal in order to protect children jump out.

119 S4: I think that the metal net may hurt children when they hit it.

120 S6: OK. I will revise it.

Most of the students' scientific argumentation in this stage was in a simple claim without justification or grounds versus another claim or counterclaim $\left(A_{C}\right)$. The total number of scientific argumentaiotn was less than the first stage of STS appraoch as previously presented.

\begin{tabular}{|c|l|c|}
\hline Code & \multicolumn{1}{|c|}{ Description } & Frequency \\
\hline$A_{C}$ & $\begin{array}{l}\text { A simple claim without justification or grounds versus another claim or } \\
\text { counterclaim. }\end{array}$ & $12(66.67 \%)$ \\
\hline$A_{G+}$ & $\begin{array}{l}\text { One or more claim(s) with simple justification or grounds (comprising data, } \\
\text { warrant, and/or qualifier and backing) but no rebuttal. }\end{array}$ & $2(11.11 \%)$ \\
\hline$A_{G++}$ & $\begin{array}{l}\text { One or more claim(s) with more detailed justification or grounds (comprising } \\
\text { data, warrant, and/or qualifier and backing) but no rebuttal. }\end{array}$ & $2(11.11 \%)$ \\
\hline$A_{G+} \mathrm{R}$ & $\begin{array}{l}\text { One or more claim(s) with justification or grounds and with a rebuttal that } \\
\text { addresses a weakness of the opposing argument and/or provides further } \\
\text { support for one's earlier argument. }\end{array}$ & $2(11.11 \%)$ \\
\hline Total & & $18(100 \%)$ \\
\hline
\end{tabular}

Table 4. Students' scientific argumentation in the Identification of the potential solution stage

\subsection{Need for Knowledge Stage}

The students were required to state knowledge or scientific concepts they need for solving the playground problems. The experiments, exercises and simulations were provided to enhance students to construct knowledge of potential energy, kinetic energy, energy formation, velocity, work and others. The example was:

212 S3: Here, the paper is attached with the ticker timer. And, then, we pull the paper. We put the mass on another side of string. The car will move and then stop. The mass put the cart move. The mass have gravitational potential energy. The cart moved. It is kinetic energy.

213 T: How do you know the kinetic energy on the car?

214 S2: The car is moving.

215 T: How much kinetic energy is?

216 S3: It is two points.

215 S4: No, it isn't. Two points are not energy. It is distance.

217 S3: We need to calculate kinetic energy

218 S2: No, we have to calculate the velocity. It will tell us how much the kinetic energy is. Ek = $1 / 2 \mathrm{mv}^{2}$ 
219 T: How does kinetic energy happen?

221 S5: The cart is moving.

223 S6: The mass pull the cart down...

312 T: Can you explain why some playground is dangerous.

313 S5: Speed of swing will be greater if we are moving down from the high.

314 S6: The lowest point of swing has the greatest speed.

315 S7: It is energy transformation from potential energy to kinetic energy

316 T: How do you know?

317 S4: At the lowest point of swing, the potential energy will be zero. And, then the swing is swung into the highest point where potential energy is greatest.

318 T: Why is it dangerous?

319 S3: If your swing is so high, the energy is so great as well.

The total number of scientific argumentaiotn in this stage was more than the two previous stages of STS appraoch. Most of the students' scientific argumentation in this stage was in higher quality scientific arguentation, that is, $A_{G^{+}}, A_{G^{+}}$and $A_{G^{+}} R$.

\begin{tabular}{|c|l|c|}
\hline Code & \multicolumn{1}{|c|}{ Description } & Frequency \\
\hline$A_{C}$ & $\begin{array}{l}\text { A simple claim without justification or grounds versus another claim or } \\
\text { counterclaim. }\end{array}$ & $7(10.93 \%)$ \\
\hline$A_{G+}$ & $\begin{array}{l}\text { One or more claim(s) with simple justification or grounds (comprising data, } \\
\text { warrant, and/or qualifier and backing) but no rebuttal. }\end{array}$ & $24(37.50 \%)$ \\
\hline$A_{G++}$ & $\begin{array}{l}\text { One or more claim(s) with more detailed justification or grounds (comprising } \\
\text { data, warrant, and/or qualifier and backing) but no rebuttal. }\end{array}$ & $19(29.68 \%)$ \\
\hline$A_{G+} \mathrm{R}$ & $\begin{array}{l}\text { One or more claim(s) with justification or grounds and with a rebuttal that } \\
\text { addresses a weakness of the opposing argument and/or provides further } \\
\text { support for one's earlier argument. }\end{array}$ & $14(21.87 \%)$ \\
\hline Total & \multicolumn{1}{|c|}{$64(100.00 \%)$} \\
\hline
\end{tabular}

Table 5. Students' scientific argumentation in the Need for knowledge stage

\subsection{Decision Making Stage}

The students were required to make decision based on their possible solutions in designing the playing equipments. The students must explain the principles, methods and rationale of their decisions. The following example illustrated the students' scientific argumentation during group brainstorming.

420 S1: The seesaw on the sand ground is safer than ones on the grass yard. As you have seen from the video, they place the seesaw on the sand too. My seesaw at home is the same. None is placed on the grass.

422 S1: We have to start from building the metal base, then the arms. I played it long time ago. I think the base has to be firmly tight and strong.

424 S1: See the base, there is a hole to put another piece of metal pole to tight it up.

425 S2: The cushion seat is made with the handlers.

426 S1: With the handlers

427 S2: Without the handlers, you will be easy to fall.

428 S1: Make the handlers like a bicycle one. The sand ground is safe. 
429 S2: We have a safety belt too.

430 S4: The sand ground lasts longer, compared to the grass ground. I mean the sand is easier due to its maintenance. The grass is so irritating and easily rotten by water.

431 S2: Should we make the cushion seat on both sides.

433 S2: If we make 5-meter height seesaw?

434 S4: Too high is unsafe.

436 S2: So, we should make it about 3.5-meter height?

437 S4: Let's do 1-meter height because the children are not that tall.

The total number of scientific argumentaiotn in this stage was higher than the previous three stages of STS appraoch. Almost al lof the students' scientific argumentation in this stage was in high quality scientific arguentation, that is, $\mathrm{A}_{\mathrm{G}}, \mathrm{A}_{\mathrm{G}+}$ and $\mathrm{A}_{\mathrm{G}} \mathrm{R}$.

\begin{tabular}{|c|l|c|}
\hline Code & \multicolumn{1}{|c|}{ Description } & Frequency \\
\hline$A_{C}$ & $\begin{array}{l}\text { A simple claim without justification or grounds versus another claim or } \\
\text { counterclaim. }\end{array}$ & $20(7.27 \%)$ \\
\hline$A_{G+}$ & $\begin{array}{l}\text { One or more claim(s) with simple justification or grounds } \\
\text { (comprising data, warrant, and/or qualifier and backing) but no rebuttal. }\end{array}$ & $120(43.63 \%)$ \\
\hline$A_{G++}$ & $\begin{array}{l}\text { One or more claim(s) with more detailed justification or grounds (comprising } \\
\text { data, warrant, and/or qualifier and backing) but no rebuttal. }\end{array}$ & $89(32.36 \%)$ \\
\hline$A_{G+} \mathrm{R}$ & $\begin{array}{l}\text { One or more claim(s) with justification or grounds and with a rebuttal that } \\
\text { addresses a weakness of the opposing argument and/or provides further } \\
\text { support for one's earlier argument. }\end{array}$ & $46(16.72 \%)$ \\
\hline Total & \multicolumn{1}{|c|}{$275(100.00 \%)$} \\
\hline
\end{tabular}

Table 6. Students' scientific argumentation in the Dcision making stage

\subsection{Socialization Stage}

The students were required to socialize with their classrmate and teacher by sharing and presenting their ideas or prototype to the class. This sharing activity enhanced the studensts' scientific argumentation.

816 S1: My group developed the safe slider. It should be safe playground because it made from good materials including Grade A plastic and metal, Galvanizing coating and cement. We provide some playing instruction. A person, who is playing on it, should keep your hand to protect player from accidents. The height of slight was provided around 60 meters. Based on this height, the player will slide down on speed of $40 \mathrm{~km} / \mathrm{hr}$.

817 S3: It is too high. It probably is dangerous based on that speed of moving down. And, the instrument needs the big area to install.

818 S2: At the highest of slider, the gravitational potential energy is greatest. The energy will be changed when people are sliding down. The potential energy will be changed into kinetic energy. The energy never lost but it will change into the new form of energy.

819 T: The 60-meter height is too high. You may imagine that it should be the same level of high building.

820 S3: Yes, but we provide someone to suggest a player how to play. And, we think that it should be ok because we learn from VDO clip of Japanese slider. They also provided the sliders with the same height. And, we have to provide some playing instruction for more safety.

821 T: How can you do for more safe? 
822 S2: We will provide some officers to take care that sliders.

823 S11: Do you limit the age of player?

826 S7: I think the 10 year player could not be allowed. It's too young.

The total number of scientific argumentaiotn in this stage was higher than the previous four stages of STS appraoch. Almost al lof the students' scientific argumentation in this stage was in high quality scientific arguentation, that is, $A_{G+}, A_{G+}$ and $A_{G+} R$. The propertion of all four types of scientific argumentation in this stage is similar to the previous stage.

\begin{tabular}{|c|l|c|}
\hline Code & \multicolumn{1}{|c|}{ Description } & Frequency \\
\hline$A_{C}$ & $\begin{array}{l}\text { A simple claim without justification or grounds versus another claim or } \\
\text { counterclaim. }\end{array}$ & $35(9.35 \%)$ \\
\hline$A_{G+}$ & $\begin{array}{l}\text { One or more claim(s) with simple justification or grounds (comprising data, } \\
\text { warrant, and/or qualifier and backing) but no rebuttal. }\end{array}$ & $118(31.55 \%)$ \\
\hline$A_{G++}$ & $\begin{array}{l}\text { One or more claim(s) with more detailed justification or grounds (comprising } \\
\text { data, warrant, and/or qualifier and backing) but no rebuttal. }\end{array}$ & $148(39.57 \%)$ \\
\hline$A_{G+} \mathrm{R}$ & $\begin{array}{l}\text { One or more claim(s) with justification or grounds and with a rebuttal that } \\
\text { addresses a weakness of the opposing argument and/or provides further } \\
\text { support for one's earlier argument. }\end{array}$ & $73(19.51 \%)$ \\
\hline Total & \multicolumn{1}{|c|}{} & $374(100.00 \%)$ \\
\hline
\end{tabular}

Table 7. Students' scientific argumentation in the Socialization stage

In overall, the STS learning unit on Work and Energy helps the participating students develop a number of high quality scientific argumentation. When the students learn stage-by-stage according to the STS approach, they develop more quality scientific argumentation especially in the Need for knowledge, Decision making and Socialization stages. This study shows that one effective way to enhance students to generate more quality scientific argumentation skill can be occurred through socialization process in classroom between student-student and/or student-teacher (Dawson \& Venville, 2010; Vygotsky, 1978). In addition, when students try to find out needed knowledge to solve problems and make their decision according to derived knowledge, they have more opportunity to develop their scientific argumentation (Abell, Anderson \& Chezem, 2000; Aufschnaiter, Erduran, Osborne \& Shirley, 2008; Zohar \& Nemet, 2002). However, interestingly, there was no scientific argumentation in the AG+RS category.

\section{Conclusion}

The conclusion made fom this study is that the STS-based learning unit on Work and Energy is effective, to some extent, in helping the participating Grade 10 students develop the quality of their scientific argumentation. The three prominent stages in the STS learning stages that help the participating students develop good quality of scientific arguementation are: the Need for knowledge, Decision making and Socialization stages.

STS approach is effective in helping science students enhance their scientific argumentation. The playground issue is appeared as one interesting and effective controversial societal issue for students who learn with the STS approach. The STS playground unit can enhance students to increase quality of their scientific argumentation. Particularly, this study indicates that the Need for knowledge, Decision making and Socialization stages according to Yuenyong's (2006) STS framework provide students opportunity to develop high quality scientific argumentation.

\section{Implications}

This study affirms that the STS approach is effective in helping science students enhance their scientific argumentation. The playground issue is appeared as one interesting and effective controversial societal issue for students who learn with the STS approach. The STS playground unit can enhance students to 
increase quality of their scientific argumentation. Particularly, this study indicates that the Need for knowledge, Decision making and Socialization stages provide students opportunity to develop high quality scientific argumentation.

There is a difficulty in seeking for interesting, controversial issues to suit with the targeted physics topic. Science teachers who are interested in using the STS approach to promote their students' scientific argumentation may need to understand about the basic principle of STS philosophy and approach. Also, a variety of example of STS learning units covered different science subjects and grade levels of students should be provided in order to make science teachers gain some ideas about what the STS teaching and learning look like. In addition, science teacher training on STS approach is demanded.

\section{Declaration of Conflicting Interests}

The authors declared no potential conflicts of interest with respect to the research, authorship, and/or publication of this article.

\section{Funding}

This research was supported by the Higher Education Research Promotion and National Research University Project of Thailand, Office of the Higher Education Commission, through the Cluster of Research to Enhance the Quality of Basic Education. The authors would like to express sincere gratitude to the Office of the Higher Education Commission.

\section{References}

Abell, S.K., Anderson, G., \& Chezem, J. (2000). Science as argument and explanation: Exploring concepts of sound in third grade. In Minstrell, J. \& Zee, E.H.V. (Eds.), Inquiry into inquiry learning and teaching in science (100-119). n.p.

Aikenhead, G.S., \& Ryan, A.G. (1992). The development of a new instrument: View on science technology- society (VOSTS). Science education, 76(5), 447-491. https://doi.org/10.1002/sce.3730760503

Aufschnaiter, C., Erduran, S., Osborne, J., \& Shirley, S. (2008). Arguing to learn and learning to argue: Case studies of how students' argumentation relates to their scientific knowledge. Journal of Research in Science Teaching, 45(1), 101-131. https://doi.org/10.1002/tea.20213

Berland, L.K., \& Reiser, B.J. (2009). Making sense of argumentation and explanation. Science education, 93(1), 26-55. https://doi.org/10.1002/sce.20286

Chin, C. \& Osborne, J. (2010). Supporting argumentation through students' questions: Case studies in science classrooms. Journal of the Learning Sciences, 19(2), 230-284.

https://doi.org/10.1080/10508400903530036

Dawson, V.M., \& Venville, G. (2010). Teaching strategies for developing students' argumentation skills about socioscientific issues in high school genetics. Research in Science Education, 40(2), 133-148.

https://doi.org/10.1007/s11165-008-9104-y

Driver, R., Newton, P., \& Osborne, J. (2000). Establishing the norms of scientific argumentation in classroom. Science education, 84(3), 287-312. https://doi.org/10.1002/(SICI)1098-237X(200005)84:3<287::AIDSCE1 3 3.0.CO;2-A

Erduran, S., Simon, S., \& Osborne, J. (2004). TAP ping into argumentation: Developments in the use of Toulmin's Argument Pattern for studying science discourse. Science education, 88(6), 915-933.

https://doi.org/10.1002/sce.20012

Kuhn, D. (1993). Science as argument: implications for teaching and learning scientific thinking. Science education, 7, 319-337. https://doi.org/10.1002/sce.3730770306 
Lin, S.S., \& Mintzes, J.J. (2010). Learning argumentation skills through instruction in socio scientific issues: The effect of ability level. International Journal of Science and Mathematics Education, 8(6), 993-1017. https://doi.org/10.1007/s10763-010-9215-6

Ministry of Education (2001). Basic Education Curriculum B.E. 2544. Bangkok: The Printing House of Express Transportation Organization of Thailand.

Office of the Education Council (2011). Strategic development of buman capital of the country in the Education Reform in the Second Decade B.E. 2552-2561 (2009-2018). Bangkok: Office of the education Council.

Office of the National Education Commission (1999). National Education Act B.E. 2542. Bangkok: Office of the National Education Commission.

Office of the National Education Commission (2002). The National Education Act B.E. 2542 (1999) and Amendments (second national education act B.E.2545). Bangkok: Pimdeekarnpim.

Protjanatanti, N. (2001). Teaching and learning by STS approach. Songklanakarin Journal of Social Sciences and Humanities, 7(2), 225-233.

Sampson, V., Grooms, J., \& Walker, J. (2009). Argument-Driven Inquiry to promote learning and interdisciplinary work in science classrooms. The Science Teacher, 76(8), 42-47.

Sturman, A. (1997). Case study methods. In Keeves, J.P. (Ed.), Educational research methodology and measurement: An international handbook (61-66). Cambridge: Cambridge University Press.

Toulmin, S. (1958). The uses of argument. Cambridge, England: Cambridge University Press.

Toulmin, S. (2003). The uses of argument. Cambridge, England: Cambridge University Press. https://doi.org/10.1007/s10763-010-9215-6

Vygotsky, L.S. (1978). Mind in society: The development of high-Erpsychological processes. Cambridge: MA: Harvard University Press.

Yuenyong, C. (2006). Teaching and learning about energy: Using STS approach (Ph.D. Dissertation in Science Education). Kasetsart University, Bangkok.

Ziman, J. (1978). Reliable knowledge. Cambridge: Cambridge University Press.

Zohar, A., \& Nemet, F. (2002). Fostering students' knowledge and argumentation skills through dilemmas in human genetics. Journal of Research in Science Teaching, 39, 35-62. https://doi.org/10.1002/tea.10008

Published by OmniaScience (www.omniascience.com)

Journal of Technology and Science Education, 2019 (www.jotse.org)

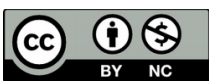

Article's contents are provided on an Attribution-Non Commercial 4.0 Creative commons International License. Readers are allowed to copy, distribute and communicate article's contents, provided the author's and JOTSE journal's names are included. It must not be used for commercial purposes. To see the complete licence contents, please visit https://creativecommons.org/licenses/by-nc/4.0/. 